\title{
Tingkat Ketahanan Pangan Rumah Tangga Petani Sebelum dan Selama Pandemi Covid 19 Di Desa Gohong Kabupaten Pulang Pisau
}

\author{
Novia Wulandari, Emmy Uthanya Antang, Betrixia Barbara, Evi Feronika dan Masliani \\ Jurusan Sosial Ekonomi Pertanian, Universitas Palangka Raya \\ Email: novia7390@gmail.com
}

\begin{abstract}
Pulang Pisau Regency has a total consumption of rice that $1.140 \mathrm{kcal} / \mathrm{capita} / \mathrm{day}$, less than the standard calorie intake of $2.200 \mathrm{kcal} / \mathrm{capita} / \mathrm{day}$. This study aimed to determine the level of household food security before and during the Covid-19 pandemic in Gohong Village, Pulang Pisau regency. This research was conducted in Gohong Village, Pulang Pisau Regency. Purposive selection of the location. Research conducted for 3 (three) months starting from October to December 2020. The number of samples was taken 20 households, the method used in determining the sample was the proportional simple random sampling technique. The data collected includes primary and secondary data. The analysis tools used is the share of food expenditure and energy adequacy. The results showed that the level of energy consumption from rice in the household was on average 888.46 calories/person/day, only reaching $44.42 \%$ of the energy adequacy of 2,000 calories/person/day. $25 \%$ of the household can achieve energy sufficiency from grains. $40 \%$ households were in the Food Expenditure Share above $60 \%$ before the Covid 19 Pandemic, and 35\% households were in the Covid 19 Pandemic. $15 \%$ households were in food secure before the Pandemic it increased to $20 \%$ while Pandemic Covid 19. Increment in the number of households food secure was due to the decrease in the number of households with a Food Expenditure Share above $60 \%$. The number of households on criteria food insecure before the pandemic was $85 \%$ consisting of $10 \%$ vulnerable, $45 \%$ lack of food, and $30 \%$ food insecurity. Meanwhile, during the pandemic, $80 \%$ of households were on the criteria food insecure, consisting of $5 \%$ vulnerable food, $45 \%$ lack of food, and $30 \%$ food insecure.
\end{abstract}

Keywords : Food Security, Covid-19 Pandemic, Farmers Household

\section{Pendahuluan}

Dalam Undang-Undang Nomor 18 Tahun 2012 tentang pangan, disebutkan bahwa penyelenggaraan pangan bertujuan untuk meningkatkan kemampuan memproduksi pangan secara mandiri, menyediakan pangan yang beraneka ragam dan memenuhi persyaratan keamanan, mutu, dan gizi bagi konsumsi masyarakat mewujudkan tingkat kecukupan pangan, terutama pangan pokok dengan harga yang wajar dan terjangkau sesuai dengan kebutuhan masyarakat, mempermudah akses pangan bagi masyarakat, terutama masyarakat rawan pangan dan gizi; meningkatkan nilai tambah dan daya saing komoditas pangan di pasar dalam negeri dan luar negeri; meningkatkan pengetahuan dan kesadaran masyarakat tentang pangan; meningkatkan kesejahteraan bagi petani, nelayan, pembudi daya ikan, dan pelaku usaha pangan dan melindungi serta mengembangkan kekayaan sumber daya pangan nasional. Terpenuhinya kebutuhan pangan secara adil, merata, dan berkelanjutan dapat dinilai dari ketahanan pangan.

Ketahanan pangan adalah kondisi terpenuhinya pangan bagi negara sampai dengan perseorangan, yang tercermin dari tersedianya Pangan yang cukup, baik jumlah maupun mutunya, aman, beragam, bergizi, merata, dan terjangkau serta tidak bertentangan dengan agama, keyakinan, dan budaya masyarakat, untuk dapat hidup sehat, aktif, dan produktif secara berkelanjutan (UndangUndang RI Nomor 18 Tahun 2012). Terdapat 4 (empat) dimensi ketahanan pangan, yaitu: ketersediaan pangan, akses pangan, penggunaan pangan, serta stabilitas ketersediaan, akses, dan pengunaan pangan (Gross, et al, 2000; Suharyanto, 2011; Suryana, 2014; Leroy, et al, 2015). Ketersediaan pangan pada tingkat nasional, regional, atau wilayah tidak menjamin ketersediaan pada tingkat rumahtangga, oleh karenanya perlu melakukan penilaian ketahanan pangan pada tingkat mikro, yaitu rumahtangga. Ketahanan pangan dengan banyak dimensi, sehingga dalam penilaiannya 
mengkombinasikan indikator dari dimensi-dimensi tersebut. Salah satu cara untuk mengukur tingkat ketahanan pangan adalah dengan mengukur konsumsi energi dan Pangsa Pengeluaran Pangan. Maxwell, et al (2000) mengunakan cut off $80 \%$ konsumsi energi dari Angka Kecukupan Energi (AKE) yang telah ditetapkan, dan Pangsa Pengeluaran Pangan dengan cut off $60 \%$ pengeluaran pangan dari total pengeluaran. Hasil penelitian Ilham dan Sinaga (2012) menyimpulkan bahwa pangsa pengeluaran pangan layak dijadikan indikator ketahanan pangan karena mempunyai hubungan yang erat dengan berbagai ukuran ketahanan pangan yaitu tingkat konsumsi, keanekaragaman pangan, dan pendapatan.

Kabupaten Pulang Pisau merupakan salah satu diantara Kabupaten pemekaran di wilayah Kalimantan Tengah yang mempunyai wilayah seluas $8.997 \mathrm{~km}^{2}$ atau $889.700 \mathrm{Ha}$ dengan jumlah penduduk 126.181 jiwa. Dalam rencana strategis Tahun 2018-2023 Pemerintah Kabupaten Pulang Pisau melalui Dinas Ketahanan Pangan mencanangkan visi terwujudnya ketahanan pangan rumah tangga yang mandiri berbasis sumber daya lokal yang efektif, berkelanjutan menuju Kabupaten Pulang Pisau yang sejahtera 2023. Konsumsi energi yang dihitung dari konsumsi beras pada tingkat kabupaten/wilayah hanya sebesar $1.140 \mathrm{kkal} / \mathrm{kapita} / \mathrm{hari}$, kurang dari standar asupan kalori yaitu sebesar $2.200 \mathrm{kkal} / \mathrm{kapita} / \mathrm{hari}$ (Dinas Ketahanan Pangan Pulang Pisau, 2018) dan pengeluaran ratarata perkapita penduduk kabupaten pulang pisau lebih banyak dihabiskan untuk konsumsi pangan dibandingkan dengan konsumsi non pangan (BPS Kabupaten Pulang Pisau, 2018).

Pandemi Covid-19 menghambat seluruh aktivitas masyarakat, termasuk aktivitas ekonomi masyarakat. Terganggunya ekonomi masyarakat akan berdampak pada penyediaan pangan rumah tangga, dan akan mempengaruhi ketahanan pangan rumah tangga. Desa gohong adalah salah satu desa di Kabupaten Pulang Pisau Kecamatan Kahayan Hilir yang mayoritas masyarakatnya adalah petani, yang diharapkan masyarakatnya memiliki ketahanan pangan rumah tangga karena mampu menyediakan pangannya sendiri. Disamping itu, Desa Gohong merupakan salah satu Desa pendukung pangan sehingga kegiatan sarana dan prasarana pertanian dan perkebunan serta pemerintahan masih menjadi prioritas (Badan Restorasi Gambut Kalimantan Tengah, 2018). Penelitian ini bertujuan untuk Menganalisis tingkat Konsumsi energi bersumber beras dan ketahanan pangan rumah tangga di Desa Gohong Kabupaten Pulang Pisau sebelum dan selama adanya Pandemi Covid-19.

\section{Bahan dan Metode}

Penelitian dilaksanakan selama 3 (tiga) bulan dari bulan Oktober sampai dengan Desember 2020, yang dilaksanakan di Desa Gohong Kecamatan Kahayan Hilir Kabupaten Pulang Pisau Provinsi Kalimantan Tengah. Pemilihan tempat penelitian dilakukan secara sengaja (purposive) dengan pertimbangan mayoritas rumahtangga adalah petani.

Metode penelitian survey dengan populasi adalah rumahtangga petani, jumlah sampel sebanyak 20 rumahtangga yang ditetapkan dengan metode proportional simple random sampling. Data dilakukan dengan wawancara dengan panduan kuisioner terhadap ibu rumahtangga, pengukuran konsumsi beras, dan pengamatan langsung di pangan.

Tingkat ketahanan pangan rumahtangga ditetapkan dengan 2 (dua) indikator, yaitu konsumsi energi dan pangsa pengeluaran pasar, dengan 4 (empat) tingkat ketahanan pangan, yaitu: Tahan Pangan, Kurang Pangan, Rentan Pangan, dan Rawan Pangan, Penetapan dilakukan dengan pengukuran seperti pada Tabel 1.

Penetapan kecukupan energi dilakukan dengan mengukur konsumsi energi dari konsumsi beras dibandingkan dengan angka kecukupan energi yang dianjurkan dalam angka kecukupan gizi (AKG). Guna mendukung penilaian terhadap ketahanan pangan dilakukan pula penilaian konsumsi keragaman pangan dengan menggunakan tabel food frequency. 
Tabel 1. Kriteria Penetapan Tingkat Ketahanan Pangan Rumahtangga

\begin{tabular}{|c|c|c|}
\hline \multirow[b]{2}{*}{ Kategori angka kecukupan energi ${ }^{*}$} & \multicolumn{2}{|c|}{ Pangsa pengeluaran pangan } \\
\hline & $\begin{array}{c}\text { Rendah } \\
(<60 \% \text { Pengeluaran total })\end{array}$ & $\begin{array}{c}\text { Tinggi } \\
(\geq 60 \% \text { Pengeluaran total) }\end{array}$ \\
\hline $\begin{array}{l}\text { Cukup } \\
>50 \% \text { Kecukupan energi }\end{array}$ & Tahan pangan & Rentan pangan \\
\hline $\begin{array}{c}\text { Kurang } \\
\leq 50 \% \text { Kecukupan energi }\end{array}$ & Kurang pangan & Rawan pangan \\
\hline
\end{tabular}

Keterangan:

*) Modifikasi Maxwell, et al. (2000)

Kecukupan Konsumsi Energi berdasarkan PPH

\section{Hasil dan Pembahasan}

Karakteristik rumahtangga responden menunjukkan rata-rata usia adalah 44,2 tahun dengan kisaran antara 26 - 51 tahun, seluruh responden berada pada kelompok usia produktif. Tingkat pendidikan dari SD, SMP, dan SMA dengan persentase masing-masing 35 persen, 35 persen, dan 30 persen. Jumlah anggota keluarga berkisar antara $3-7$ orang, dengan rata-rata jumlah anggota keluarga 4 orang, rumahtangga paling banyak berada pada kisaran 4-6 orang. Sedangkan pendapatan rumahtangga berkisar antara Rp. 1.300.000,00 - Rp. 3.500.000,00 dengan rata-rata Rp. 2.095.000,00 sebelum Pandemi Covid 19 dan antara Rp. 1.000.000,00 - Rp. 3.500.000,00 dengan rata-rata Rp. 1.935.000,00 setelah Pandemi Covid 19. Sebanyak 7 rumahtangga mengalami penurunan pendapatan selama Pandemi Covid 19, dengan penurunan pendapatan berkisar antara Rp. 200.000,00 - Rp. 800.000,00. Berdasarkan kriteria Badan Pusat Statitik, tingkat pendapatan rumahtangga responden berada pada kategori rumahtangga berpendapatan sedang yang berkisar antara Rp. 1.500.000,00 - Rp. $2.500 .000,00$.

Tabel 2. Keadaan Umum Rumah Tangga Petani Responden di Desa Gohong, Kecamatan Kahayan Hilir Kabupaten Pulang Pisau

\begin{tabular}{llcc}
\hline No & Karakteristik & Jumlah & Persentase (\%) \\
\hline 1. & Tingkat Usia (Tahun) & 44,2 & - \\
& a. Rata-rata & 26 & - \\
& b. Usia minimum & 51 & - \\
\hline c. Usia maksimum & & 35,0 \\
\hline 2. & Tingkat Pendidikan (Orang) & 7 & 35,0 \\
\hline & a. SD & 7 & 30,0 \\
b. SMP & 6 & 30,0 \\
& c. SMA & & 65,0 \\
\hline 3. Jumlah Anggota Keluarga (Orang) & 6 & 5,0 \\
\hline & a. 1-3 & 13 & \\
& b. 4-6 & 1 & 30,0 \\
& c. 7-9 & & 65,0 \\
\hline Jumlah Pendapatan & 6 & 5,0 \\
\hline & a. $1.000 .000-1.999 .000$ & 13 & \\
b. 2.000.000 - 2.999.000 & 1 & \\
& c. $3.000 .000-4000.000$ & &
\end{tabular}

Sumber: Data Primer Yang Diolah, 2021

Tabel 3 menunjukkan rata-rata pengeluaran rumahtangga per bulan untuk belanja pangan dan pangan. Rata-rata pengeluaran rumahtangga untuk belanja pangan sebelum dan selama Pandemi 
Covid 19 lebih besar dari pada pengeluaran untuk belanja non pangan, dimana pengeluaran untuk pangan sebesar Rp. 1.040.000,00 (57,6 \%) sebelum Pandemi Covid 19 dan Rp.1.026.500,00 (58,7 \%) selama Pandemi Covid 19; sedangkan pengeluaran unttuk non pangan sebesar Rp. 766.000,00 (42,4 \%) sebelum Pandemi Covid 19 dan Rp. 723.000,00 (41,3 \%) selama Pandemi Covid 19.

Pengeluaran pangan terbesar adalah untuk belanja beras yang mencapai $32-33 \%$ dari total pengeluaran keseluruhan atau $55-58 \%$ dari total pengeluaran pangan. Hal ini mengindikasikan bahwa rumahtangga petani menyediakan beras dengan membeli. Jumlah beras yang dikonsumsi selama Pandemic Covid 19 tidak berbeda dengan sebelum Pandemi Covid 19 namun jumlah uang yang dibelanjakan lebih kecil pada saat Pandemi Covid 19, hal ini dapat diduga bahwa rumahtangga membeli beras dengan harga yang lebih murah pada masa Pandemi Covid 19. Belanja pangan lainnya yang mengalami penurunan selama Pandemi Covid 19 adalah Telur dan Susu, dan bahan minuman. Sedangkan belanja pangan yang mengalami peningkatan adalah untuk ikan, sayuran, dan buahbuahan. Peningkatan pengeluaran untuk jenis pangan tertentu tidak dapat disimpulkan disebabkan oleh peningkatan jumlah pembelian, namun dapat disebabkan karena harga yang meningkat selama masa Pandemi Covid 19.

Tabel 3. Rata-rata Pengeluaran Per Bulan Konsumsi Pangan dan Non Pangan Rumah Tangga Petani Sebelum dan Selama Covid-19

\begin{tabular}{|c|c|c|c|c|c|}
\hline \multirow[b]{2}{*}{ No. } & \multirow{2}{*}{ I. Pengeluaran Pangan } & \multicolumn{2}{|c|}{$\begin{array}{c}\text { Sebelum pandemi } \\
\text { Covid-19 }\end{array}$} & \multicolumn{2}{|c|}{$\begin{array}{c}\text { Selama Pandemi } \\
\text { Covid-19 }\end{array}$} \\
\hline & & $\begin{array}{l}\text { Rata-rata } \\
\text { (Rp) }\end{array}$ & $(\%)$ & $\begin{array}{c}\text { Rata-rata } \\
\text { (Rp) }\end{array}$ & $(\%)$ \\
\hline 1. & Beras & 600.000 & 33,0 & 560.000 & 32,0 \\
\hline 2. & Umbi-umbian & - & - & - & - \\
\hline 3. & Tempe & 48.000 . & 2,6 & 48.000 & 2,7 \\
\hline 4. & Tahu & 40.000 & 2,2 & 37.000 & 2,1 \\
\hline 5. & Ikan & 40.000 & 2,2 & 80.000 & 4,6 \\
\hline 6. & Daging & 60.000 & 3,3 & 60.000 & 3,4 \\
\hline 7. & Telur dan Susu & 56.000 & 3,1 & 36.000 & 2,0 \\
\hline 8. & Sayuran & 25.000 & 1,4 & 40.000 & 2,3 \\
\hline 9. & Kacang-kacangan & - & - & - & - \\
\hline 10. & Buah-buahan & 15.000 & 0,8 & 15.500 & 0,9 \\
\hline 11. & Bahan minuman & 6.000 & 0,3 & - & - \\
\hline 12. & Konsumsi lainnya & - & - & - & - \\
\hline 13. & Makanan dan Minuman jadi & - & - & - & - \\
\hline \multirow[t]{3}{*}{14.} & Jajanan & 150.000 & 8,3 & 150.000 & 8,6 \\
\hline & Total Pengeluaran Pangan & 1.040 .000 & 57,6 & 1.026 .500 & 58,7 \\
\hline & \multicolumn{5}{|l|}{ II. Pengeluaran Non Pangan } \\
\hline 1. & Bahan Bakar & 86.000 & 4,7 & 92.000 & 5,2 \\
\hline 2. & Penerangan & 100.000 & 5,5 & 80.000 & 4,6 \\
\hline 3. & Air & 20.000 & 1,1 & 40.000 & 2,3 \\
\hline 4. & Aneka Barang dan Jasa & - & - & - & - \\
\hline 5. & Sandang & 65.000 & 3,6 & 120.000 & 6,8 \\
\hline 6. & Pajak, Pungutan, Asuransi & - & 0 & - & - \\
\hline 7. & Tembakau/Rokok & 450.000 & 25,0 & 300.000 & 17,1 \\
\hline 8. & Bepergian/Rekreasi & - & 0 & - & - \\
\hline 9. & Pengeluaran Kesehatan & 20.000 & 1,1 & 56.000 & 3,2 \\
\hline \multirow[t]{3}{*}{10.} & Pengeluaran Pendidikan & 25.000 & 1,4 & 35.000 & 2,0 \\
\hline & Total Pengeluaran Non Pangan & 766.000 & 42,4 & 723.000 & 41,3 \\
\hline & Total I+II & 1.806 .000 & 100,0 & 1.749 .500 & 100,0 \\
\hline
\end{tabular}

Sumber : Data primer yang diolah, 2021

Pengeluaran non pangan terbesar adalah untuk belanja rokok/tembakau yang mencapai $25 \%$ sebelum Pandemi Covid 19 dan 17,1 \% selama Pandemi Covid, walaupun terjadi penurunan jumlah 
belanja selama Pandemi Covid 19 namun merupakan pengeluaran terbesar dari total keseluruhan pengeluaran non pangan. Pengeluaran non pangan yang mengalami kenaikan selama Pandemi Covid 19 adalah untuk belanja bahan bakar, air, sandang dan jasa, kesehatan, dan pendidikan. Peningkatan pengeluaran untuk kesehatan dan pendidikan selama pandemic dapat diduga karena peningkatan kebutuhan selama pandemi, seperti: masker, alat dan bahan sanitasi, dan kuota internet.

Konsumsi energi rumahtangga dapat digunakan sebagai salah satu indicator untuk menilai ketahanan pangan rumahtangga. Maxwell, et al (2000) mengelompokkan Ketahanan Pangan berdasarkan pada perhitungan Konsumsi Energi dan Pangsa Pengeluaran Pangan. Selanjutnya disebutkan bahwa konsumsi cukup apabila sama dengan atau lebih dari $80 \%$ Angka Kecukupan Energi (AKE) dan tidak cukup apabila konsumsi energi kurang dari $80 \%$ AKE. Pangan pokok masyarakat Indonesia pada umumnya, termasuk di Desa Gohong, adalah beras dan sebagian besar pemenuhan energi didapatkan dari konsumsi beras. Tabel 4 berikut menunjukkan konsumsi energi rumahtangga berasal dari konsumsi beras. Berdasarkan hasil penelitian hanya 3 (tiga) rumahtangga (15\%) yang dapat dikelompokkan pada konsumsi energi yang cukup (berada di atas $80 \%$ AKE). Jika dinilai berdasarkan Pola Pangan Harapan (PPH) berdasarkan Widya Karya Pangan dan Gizi 2012 yang menyatakan bahwa kontribusi kelompok padi-padian sebesar 50 \%, dan sasaran PPH tahun 2018 sebesar 53,6 \% (Badan Ketahanan Pangan Kementerian Pertanian 2019), maka hanya sebanyak 5 (lima) rumahtangga (25\%) responden yang dapat memenuhi konsumsi energy berasal beras berdasarkan PPH. Dibandingkan dengan konsumsi energi berasal beras pada tingkat Kabupaten Pulang Pisau yang mencapai $57 \%$ pada tahun 2018, konsumsi rata-rata energi asal beras di Desa yaitu sebesar 888,46 Kal/orang/hari atau 44,42 \% dari Angka Kecukupan Energi 2000 Kal/orang/hari, lebih rendah dari konsumsi energi tingkat Kabupaten Pulang Pisau, PPH Widya Karya Pangan dan Gizi 2012, dan sasaran PPH Tahun 2018.

Tabel 4. Konsumsi, Kebutuhan, dan Kecukupan Energi Menurut Rumah Tangga Responden

\begin{tabular}{crrr}
\hline No Sampel & $\begin{array}{c}\text { Konsumsi } \\
\text { (Kalori) }\end{array}$ & $\begin{array}{c}\text { Kebutuhan } \\
\text { (Kalori) }\end{array}$ & $\begin{array}{c}\text { Angka Kecukupan Energi } \\
(\%)\end{array}$ \\
\hline 1. & 4.641 & 14.000 & 33 \\
2. & 3.570 & 10.000 & 36 \\
3. & 3.570 & 10.000 & 36 \\
4. & 5.355 & 6.000 & $\mathbf{8 9}$ \\
5. & 2.856 & 10.000 & 29 \\
6. & 5.712 & 12.000 & 48 \\
7. & 3.570 & 10.000 & 36 \\
8. & 9.282 & 10.000 & $\mathbf{9 3}$ \\
9. & 5.355 & 6.000 & $\mathbf{8 9}$ \\
10. & $2.677,5$ & 12.000 & 22 \\
11. & 4.641 & 10.000 & 46 \\
12. & 3.570 & 8.000 & 45 \\
13. & 5.355 & 12.000 & 45 \\
14. & 2.856 & 6.000 & 48 \\
15. & 5.355 & 10.000 & $\mathbf{5 4}$ \\
16. & 3.570 & 10.000 & 36 \\
17. & 2.856 & 8.000 & 36 \\
18. & 1.785 & 6.000 & 30 \\
19. & 1.785 & 6.000 & 30 \\
20. & 3.570 & 6.000 & $\mathbf{6 0}$ \\
\hline
\end{tabular}

Sumber : Data primer yang diolah, 2021

Tingkat ketahanan pangan diukur menggunakan cut off $50 \%$ energy bersumber beras yang didasarkan pada PPH Widya Karya Pangan dan Gizi 2012 ditunjukkan pada Tabel 5. 
Tabel 5. Tingkat Ketahanan Pangan Rumahtangga Responden di Desa Gohong Kabupaten Pulang Pisau

\begin{tabular}{llcccc}
\hline \multirow{2}{*}{ No } & Tingkat Ketahanan & \multicolumn{2}{c}{$\begin{array}{c}\text { Sebelum Pandemi } \\
\text { Covid-19 }\end{array}$} & \multicolumn{2}{c}{$\begin{array}{c}\text { Selama Pandemi } \\
\text { Covid-19 }\end{array}$} \\
\cline { 3 - 6 } & $\begin{array}{c}\text { Pangan } \\
\text { Tangga }\end{array}$ & $\%$ & $\begin{array}{c}\text { Jumlah Rumah } \\
\text { Tangga }\end{array}$ & $\%$ \\
\hline 1. & Tahan Pangan & 3 & 15 & 4 & 20 \\
\hline 2. & Rentan Pangan & 2 & 10 & 1 & 5 \\
\hline 3. & Kurang Pangan & 9 & 45 & 9 & 45 \\
\hline 4. & Rawan Pangan & 6 & 30 & 6 & 30 \\
\hline
\end{tabular}

Sumber : Data primer yang diolah, 2021

Tabel di atas menunjukkan bahwa $85 \%$ rumahtangga responden tidak tahan pangan pada saat sebelum pandemic covid 19 dan $80 \%$ pada masa Pandemi Covid 19. Sebanyak 1 (satu) rumahtangga berpindah dari kategori rentan pangan menjadi tahan pangan akibat dari Pangsa Pengeluaran Pangan pada masa Pandemi Covid 19 kurang dari $60 \%$. Rendahnya tingkat ketahanan pangan rumahtangga lebih banyak dipengaruhi oleh rendahnya konsumsi energi yang bersumber dari beras, hanya 8 rumahtangga $(40 \%)$ yang Pangsa Pengeluaran Pangannya lebih dari $60 \%$ pada masa sebelum pandemic covid 19, dan 7 rumahtangga (35\%) pada masa Pandemi covid 19. Terjadinya penurunan jumlah rumahtangga dengan Pangsa Pengeluaran Pangan di atas $60 \%$ dapat disebabkan oleh beberapa hal, antara lain: dengan pendapatan yang relative sama rumahtangga menekan belanja untuk konsumsi pangan karena meningkatnya belanja non pangan terkait dengan Pandemi Covid 19, meningkatnya harga pangan sehingga masyarakat mencari pangan dari sumber lain, seperti menangkap ikan dan memetic sayuran yang ada di sekitar rumah, kebun, dan lahan pertanian.

Berdasarkan identifikasi keragaman pangan yang dilakukan melalui tabel Frekuensi Pangan (Food Frequency), rumahtangga mengkonsumsi jenis pangan lain sebagai bahan pangan pokok selain beras, yaitu umbi dan jagung yang dikonsumsi rata-rata 1-2 kali per minggu. Sumber energi tentu tidak saja berasal dari beras, umbi dan jagung merupakan sumber energi yang baik pula, sehingga walalupun konsumsi beras belum dapat memenuhi kecukupan energi minimal yang ditetapkan, dengan konsumsi pangan pokok lainnya dapat menambah jumlah energi oleh anggota rumahtangga.

Tabel 6. Tabel Food Frequency di Desa Gohong Kecamatan Kahayan Hilir Kabupaten Pulang Pisau

\begin{tabular}{|c|c|c|}
\hline No. & Jenis Pangan & Frekuensi \\
\hline 1. & $\begin{array}{l}\text { Pangan Pokok (Sumber Energi) } \\
\text { - Nasi } \\
\text { - Umbi } \\
\text { - Jagung }\end{array}$ & $\begin{array}{l}2-3 \mathrm{kali} / \mathrm{hari} \\
1-2 \mathrm{kali} / \mathrm{minggu} \\
1-2 \mathrm{kali} / \mathrm{minggu}\end{array}$ \\
\hline 2. & $\begin{array}{l}\text { Sayuran } \\
\text { - Daun singkong } \\
\text { - Kacang Panjang } \\
\text { - Bayam } \\
\text { - Terong Asam } \\
\text { - Kangkung } \\
\text { - Pakis } \\
\text { - Sayur Manis } \\
\text { - Katuk } \\
\text { - Umbut } \\
\text { - Tauge } \\
\text { - labu Kuning } \\
\text { - Labu Putih }\end{array}$ & $\begin{array}{l}1-3 \mathrm{kali} / \mathrm{minggu} \\
1-3 \mathrm{kali} / \mathrm{minggu} \\
1-3 \mathrm{kali} / \mathrm{minggu} \\
2 \mathrm{kali} / \mathrm{minggu} \\
1-2 \mathrm{kali} / \mathrm{minggu} \\
1-3 \mathrm{kali} / \mathrm{minggu} \\
1 \mathrm{kali} / \mathrm{minggu} \\
1-3 \mathrm{kali} / \mathrm{minggu} \\
1 \mathrm{kali} / \mathrm{minggu} \\
1 \mathrm{kali} / \mathrm{minggu} \\
2 \mathrm{kali} / \mathrm{minggu} \\
1-2 \mathrm{kali} / \mathrm{minggu}\end{array}$ \\
\hline 3. & Tahu/Tempe & $1-3 \mathrm{kali} / \mathrm{minggu}$ \\
\hline 4. & Ikan & Setiap Hari, $1-5$ kali/minggu \\
\hline
\end{tabular}




\begin{tabular}{lll}
\hline 5. & Daging Ayam & $1-3 \mathrm{kali} / \mathrm{minggu}, 1-3 \mathrm{kali} / \mathrm{bulan}$ \\
\hline 6. & Telur & Setiap hari, $1-3 \mathrm{kali} / \mathrm{minggu}$ \\
\hline 7. & Susu & $4 \mathrm{kali} / \mathrm{minggu}$ \\
\hline 8. & Kacang-Kacangan & $1 \mathrm{kali} / \mathrm{minggu}$ \\
\hline 9. & Buah-buahan & $1 \mathrm{kali} / \mathrm{minggu}$ \\
& - Jeruk & $1-2 \mathrm{kali} / \mathrm{minggu}$ \\
& - Semangka & $1-3 \mathrm{kali} / \mathrm{minggu}$ \\
& - Pisang & $3 \mathrm{kali} / \mathrm{minggu}$ \\
& - Nanas & $1 \mathrm{kali} / \mathrm{bulan}$ \\
& - Mangga & $1 \mathrm{kali} / \mathrm{bulan}$ \\
& - Pepaya & $1 \mathrm{kali} / \mathrm{bulan}$ \\
\hline 10. & Bahak & $1-4 \mathrm{kali} / \mathrm{hari}$ \\
\hline 11. & Gula & $1-3 \mathrm{kali} / \mathrm{hari}$ \\
\hline 12. & Konsumsi Lainnya(Cemilan). & $2-5 \mathrm{kali} / \mathrm{minggu}$ \\
\hline
\end{tabular}

Sumber : Data primer yang diolah, 2021

Selain mengkonsumsi pangan pokok yang beragam, rumahtangga juga mengkonsumsi jenis pangan lain seperti sayuran, buah-buahan, dan lauk pauk yang beragam. Konsumsi pangan tersebut selalu dikonsumsi dalam setiap minggu, frekuensi bervariasi dari setiap sekali seminggu sampai dengan dikonsumsi setiap hari. Konsumsi pangan yang beragam sangat dianjurkan mengingat tidak ada satu jenis pangan yang dapat memberikan zat gizi secara lengkap. Lauk pauk dan kacangkacangan yang memrupakan sumber protein dan lemak dapat memberikan sumbangan energi jika dikonsumsi bersama nasi, umbi, dan jagung sebagai bahan pangan pokok.

\section{Kesimpulan}

1. Tingkat konsumsi energi bersumber beras pada rumahtangga responden di Desa Gohong Kabupaten Pulang Pisau rata-rata 888,46 Kalori/orang/hari, hanya mencapai 44,42 \% dari Angka Kebutuhan Energi sebesar 2000 Kalori/orang/hari. Dibandingkan dengan Sasaran Pola Pangan Harapan (PPH) yang ditetapkan Widya Karya Pangan dan Gizi 2012 yaitu sebesar $50 \%$ energy bersumber padi-padian, maka hanya 5 (lima) rumahtangga responden (25\%) yang dapat mencapai kecukupan energi bersumber padi-padian.

2. Sebanyak 8 rumahtangga responden (40 \%) berada pada kelompok Pangsa Pengeluaran Pangan di atas $60 \%$ sebelum Pandemi Covid 19, dan 7 rumahtangga responden (35\%) pada nasa Pandemi Covid 19.

3. Rumah tangga responden yang tahan pangan sebelum masa Pandemi Covid 19 sebanyak 32 (dua) rumahtangga (15\%) sedangkan pada masa Pandemi meningkat menjadi 4 rumahtangga $(20 \%)$. Peningkatan jumlah rumahtangga yang tahan pangan disebabkan karena menurunnya jumlah rumahtangga tangga dengan Pangsa Pengeluaran Pangan di atas $60 \%$. Jumlah rumahtangga responden tidak tahan pangan sebelum pandemi Covid 19 sebanyak $85 \%$ terdiri dari $10 \%$ rawan pangan, $45 \%$ kurang pangan, dan $30 \%$ rawan pangan. Sedangkan pada masa Pandemi Covid 19 sebanyak $80 \%$ rumahtangga tidak tahan pangan yang terdiri dari $5 \%$ rentan pangan, $45 \%$ kurang pangan, dan $30 \%$ rawan pangan.

\section{Daftar Pustaka}

Badan Restorasi Gambut. 2018. Profil Desa Peduli Gambut Desa Gohong. BRG Kalimantan Tengah. Palangka Raya.

Badan Pusat Statistik. 2019. Kabupaten Pulang Pisau Dalam Angka 2018. BPS Kabupaten Pulang Pisau. Pulang Pisau.

Dinas Ketahanan Pangan. 2018. Neraca Bahan Makanan (NBM) dan Pola Pangan Harapan (PPH) Ketersediaan Tahun 2018. DKP Kabupaten Pulang Pisau. Pulang Pisau. 
Food Agriculture Organisation. 1997. Kriteria dan Konsep Ketahanan Pangan. FAO. Jakarta.

Hardinsyah dan Martianto. 1992. Gizi Terapan. Departemen Pendidikan dan Kebudayaan, Direktorat Jenderal Pendidikan Tinggi. PAU Pangan dan Gizi, IPB. Bogor.

Hardinsyah. 2007. Review Faktor Determinan Keragaman Konsumsi Pangan. Jurnal Gizi dan Pangan. Vol. 2: 55-74.

Hardinsyah, G.K. Rana, M. Ariani, dan A. Gantina. 2012. Analisis Konsumsi Pangan dan Target Pola Pangan Harapan (PPH). Makalah dipresentasikan pada Widyakarya Pangan dan Gizi X. LIPI. Jakarta.

Hardinsyah. 2007. Review Faktor Determinan Keragaman Konsumsi Pangan. Jurnal Gizi dan Pangan. Vol. 2: 55-74.

Ilham, N dan B. M. Sinaga. 2012. Penggunaan Pangsa Pengeluaran Pangan sebagai Jurnal Sosial Ekonomi Pertanian. Vol. 7 No 3. Khomsan. 2012. Ekologi Masalah Gizi, Pangan dan Kemiskinan. Bandung: Alvabeta.

Maxwell, D., C. Levin., M. Armar-Klemesu., M. Ruel., S. Morris., C. Ahindeka. 2000. Urban Livelihoods and Food nutrition Security in Greater Accra, Ghana. IFPRI in Collabrative with Noguchi Memorial for Medical research and World Health Organization. Research Report No. 112. Washington, D.C.

Peraturan Pemerintah Nomor 28 Tahun 2004. Keamanan, Mutu, dan Gizi Pangan. 5 Oktober 2004. Lembaran Negara Republik Indonesia Tahun 2004 Nomor 28. Jakarta

Peraturan Pemerintah Nomor 17 Tahun 2015. Ketahanan Pangan dan Gizi. 19 Maret 2015. Lembaran Negara Republik Indonesia Tahun 2015 Nomor 17. Jakarta

Radita. 2013. Ketahanan Pangan Rumah Tangga Petani di Kecamatan Ponjong Kabupaten Gunung Kidul. Jurnal Agro Ekonomi. Vol. 24. No.2. Diakses Pada 20 Januari 2020.

Undang-Undang Republik Indonesia Nomor 12 Tahun 2012. Pangan. 17 Nopember 2012. Lembaran Negara Republik Indonesia Tahun 2012 Nomor 18. Jakarta.

Widyakarya Nasional Pangan dan Gizi (WKNPG). 2012. Lembaga Ilmu Pengetahuan Indonesia. Jakarta.

Yudaningrum. 2011. Analisis Hubungan Proporsi Pengeluaran dan Konsumsi Pangan dengan Ketahanan Pangan Rumah Tangga Petani di Kabupaten Kulon Progo. (Skripsi). Surakarta: Fakultas Pertanian, Universitas Sebelas Maret.

Yuliana. 2013. Ketahanan Pangan Rumah Tangga Nelayan di Kecamatan Teluk Betung Selatan Kota Bandar Lampung. Jurnal Sosial Ekonomi. Vol 1 No.2. 